Historia Slavorum Occidentis

2021, nr 4 (31)

ISSN 2084-1213

DOI: $10.15804 /$ hso210415

\author{
Bohdan GŁębocki (Poznań)
}

ORCID: 0000-0002-1008-9542

\title{
Mit handlu „żywym towarem”. Przyczynek do dziejów relacji polsko-żydowskich (na marginesie rozprawy Aleksandry Jakubczak Polacy, Żydzi i mit handlu kobietami, Warszawa 2020, ss. 247)
}

Relacje polsko-żydowskie stanowią jedno z najbardziej skomplikowanych zagadnień w dziejach Europy Środkowej. Szczególnie burzliwie przebiegały one w XIX i XX w., rozbudzając ogromne emocje. Na łamach prasowych prowadzono antyżydowską narrację, przedstawiając wiele trudnych do zweryfikowania opinii, bazujących często na stereotypach. Wśród nich uwagę przykuwa oskarżenie o handel „żywym towarem”, charakteryzujące się wyjątkową żywotnością ${ }^{1}$. Na łamach warszawskiej „Roli”, za centrum tak zwanego handlu „żywym towarem” uznano Galicję, gdzie porwania dziewcząt chrześcijańskich miały być liczone w setkach. Służbę kobiet chrześcijańskich w domach żydowskich traktowano jako wstęp do prostytucji. Szczególne związki Żydów z zepsuciem moralnym wywodzono z tradycji talmudycznej². Gło-

\footnotetext{
1 W nowoczesnej formie ten zarzut pojawił się w pierwszej połowie XIX wieku. Leonard Chodźko w opublikowanym w 1830 r. dziele Tableau de la Pologne ancienne et moderne sous le rapport géographique, statistique, géologique etc., przypisał Żydom stręczenie własnych żon i córek oraz zakładanie domów publicznych - A. Cała, Żyd - wróg odwieczny? Antysemityzm w Polsce i jego źródła, Warszawa 2012, s. 226.

2 Wpływowi Talmudu na kształtowanie moralności żydowskiej dużą uwagę poświęcał w swojej twórczości Teodor Jeske-Choiński. W kilkakrotnie wznawianej rozprawie Poznaj żyda wskazywał, że Żydzi już w średniowieczu wyspecjalizowali się w handlu ludźmi - G. Krzywiec, Polska
} 
szono, że Żydzi praktycznie zmonopolizowali przestępczość związaną z prostytucją ${ }^{3}$. Podobne tony wybrzmiewały w prasie kościelnej, w której wskazywano, że „Żyd faktoruje w nierządzie" ${ }^{4}$. Pretekstem do oskarżeń mogły być bieżące wydarzenia. U schyłku 1913 r., ujęcie przez carską policję siatki handlarzy „żywym towarem” połączone z ujawnieniem narodowości przestępców, wywołało antysemicką nagonkę prasową ${ }^{5}$.

Podobne oskarżenia pojawiały się również po odzyskaniu niepodległości. Żydów łączono z działalnością przestępczą, wśród której handel „żywym towarem” zajmował poczesne miejsce. Prasa katolicka szeroko opisywała sposoby deprawacji chrześcijan, do których zaliczano między innymi produkcję środków antykoncepcyjnych, a nawet konkursy piękności, przy czym proceder wysyłania kobiet do zagranicznych domów publicznych całkowicie utożsamiano z Żydami. Problem traktowano na tyle poważnie, że został poruszony przez prymasa Augusta Hlonda w liście pasterskim z 1936 r. O katolickie zasady moralne 6 . W latach trzydziestych w poszczególnych diecezjach powstawały komitety do walki z demoralizacją, zajmujące się między innymi przeciwdziałaniem handlowi „żywym towarem”

bez Żydów. Studia z dziejów idei, wyobrażeń i praktyk antysemickich na ziemiach polskich początku XX wieku (1905-1914), Warszawa 2017, s. 424-428. Według T. Jeske-Choińskiego w średniowieczu handel ludźmi, obok lichwy, stał się fundamentem potęgi ekonomicznej europejskich Żydów - O. Bergmann, Narodowa Demokracja wobec problematyki żydowskiej w latach 1918-1929, Poznań 1998, s. 135. Podobną opinię glosił w latach trzydziestych Henryk Rolicki (Tadeusz Gluziński) - H. Rolicki, Zmierzch Izraela, Krzeszowice 2004, s. 71 (na podstawie wydania z 1932 r.).

3 M. Moszyński, Antysemityzm w Królestwie Polskim. Narodziny nowoczesnej ideologii antyżydowskiej (1864-1914), Poznań 2017, s. 423-424.

4 Grzegorz Krzywiec przywołuje teksty redaktora naczelnego „Przeglądu Katolickiego” ks. Jana Gnatowskiego, nota bene aktywnego członka antysemickiego Towarzystwa „Rozwój”, obwiniającego Żydów o niszczenie polskiego społeczeństwa poprzez propagowanie demoralizacji - G. Krzywiec, Polska bez Żydów, Warszawa 2017, s. 411-412.

5 T. Jeske-Choiński obarczył Żydów odpowiedzialnością za stręczenie i prostytuowanie się kobiet, jako osobników wyzutych z ludzkiej etyki, którzy nie cofali się nawet przed krzywdzeniem własnych pobratymców. Taka bezduszna postawa miała wynikać z nieuznawania handlu „żywym towarem" za grzech ani za przestępstwo. W wydanej po pierwszej wojnie światowej Historii Żydów w Polsce T. Jeske-Choiński uznał handel kobietami za „największą hańbę XX stulecia” - Tamże, s. 437-438.

6 D. Pałka, Kościót katolicki wobec Żydów w Polsce międzywojennej, Kraków 2006, s. 276-281 .

7 Tamże, s. 286-287. 
Prasa obozu narodowego również zajmowała się tym problemem. Szukając genezy zjawiska cofano się nawet do czasów biblijnych, wspominając historię Jakuba sprzedanego w niewolę przez braci ${ }^{8}$. W latach trzydziestych novum w antyżydowskich oskarżeniach stanowiło nawiązanie do świata filmu. Karol Zbyszewski na łamach „Prosto z mostu” skrytykował film Białe niewolnice (tyt. oryginału Den hvide slavehandel) za całkowicie fałszywe ukazanie handlu kobietami ${ }^{9}$. Z kolei na łamach „Polski Narodowej” ukazywała się powieść w odcinkach Szatańska moc, której głównym wątkiem było zwalczanie handlarzy „żywym towarem”"

Wzmianki o handlu „żywym towarem” u schyłku wieku XIX i w początkach XX, pojawiają się w polskiej historiografii stosunkowo często, jednak zawsze jako wątek poboczny wobec głównego toku narracji. Aleksandra Jakubczak wypełnia tę lukę, stawiając problem prostytucji i emigracji, a w szczególności kreowanych wokół nich mitów, jako główny temat swojej monografii Polacy, Żydzi i mit handlu kobietami. Autorka podjęła próbę rewizji ustaleń polskiej historiografii w świetle nowych badań i przy wykorzystaniu nowych źródeł. Sięgając szeroko do obcojęzycznej literatury oraz źródeł (nie pomijając polskich) ustawia badane zagadnienie w kontekście globalnym. I jest to niewątpliwa zaleta tej monografii. Gorzej wygląda ustalenie ram czasowych. Nie są one podane wprost, za wyjątkiem informacji dotyczącej rozdziału czwartego, w którym Autorka omawia działania władz zaborczych między latami osiemdziesiątymi XIX w., a rokiem 1914. Oczywiście czytelnik może z kontekstu narracji wydedukować przyjęte ramy czasowe, brakuje natomiast z pewnością uzasadnienia takiego, a nie innego wyboru Autorki. Całkiem inaczej A. Jakubczak podchodzi do kwestii językowych, w przypadku których obszernie i rzeczowo omawia swoje decyzje, przykładowo pisownię słowa Żyd z wielkiej litery i stosowanie cudzysłowu w określeniu: handel „żywym towarem”. Nie można mieć również zastrzeżeń do uporząadkowanej i (w większości przypadków) konsekwentnie stosowanej terminologii ${ }^{11}$.

8 Sugerowano wręcz, że od tamtych czasów Żydzi handlowali niewolnikami nieustannie - Białe niewolnice, Czuwamy, 17 IX 1933, nr 59, s. 1.

9 Według K. Zbyszewskiego film ukazywał jako handlarzy Polaków, a jako ofiary żydowskie dziewczęta. Co ciekawe, ten duński film pochodził z 1910 r. - K. Zbyszewski, Fałszerstwa filmowe, Prosto z mostu, 22 I 1939, nr 4, s. 8.

10 Powieść drukowano od marca 1937 r. do kwietnia 1938 r. Nie można wykluczyć, że pomimo podawania jednego autora - S. Olańskiego - w rzeczywistości było ich więcej, o czym świadczą liczne niekonsekwencje, wśród nich zmiana nazwiska głównego bohatera w jednym z odcinków. 11 Wyjątek dotyczy wymiennego operowania pojęciem Europy Środkowej (Centralnej) i Europy Wschodniej na określenie tego samego obszaru. 
Praca została podzielona na siedem rozdziałów, w układzie rzeczowym, z których każdy zawiera podrozdziały ${ }^{12}$. Zaproponowany podział - jak zawsze w naukach humanistycznych - może wzbudzać kontrowersje i wątpliwości. Nie wnikając w słuszność wyborów Autorki, warto skupić się na tytułach nie do końca ściśle odzwierciedlających zawartość rozdziału. I tak rozdział piąty nosi tytuł „Zorganizowana walka $\mathrm{z}$ handlem kobietami na ziemiach polskich" sugerując, że będą w nim omówione działania zarówno struktur państwowych, jak i organizacji społecznych. Tymczasem rozdział ów dotyczy wyłącznie inicjatyw społecznych, gdyż działania organów państwa omówiono w rozdziale czwartym. Problem rozwiązałoby zawężenie zakresu w tytule. Z kolei rozdział szósty „Fala ataków na domy publiczne i handlarzy kobietami” (wydzielony być może w „ostatniej chwili”, o czym wspomniano wyżej) wpisuje się całkowicie w tematykę rozdziału piątego. W tym przypadku stosowne byłoby podkreślenie oddolnego charakteru opisywanych ataków - żeby uniknąć zarzutu o wprowadzanie w błąd czytelnika. Oczywistym mankamentem w strukturze pracy jawi się natomiast brak wydzielonego zakończenia.

Autorka podejmuje próbę wyjaśnienia rozbieżności między realną skalą handlu „żywym towarem”, a jego przedstawionym obrazem w latach poprzedzających wybuch pierwszej wojny światowej. Przekonująco dowodzi, iż rzeczywista skala była znacznie niższa, przywołując źródła argentyńskie oraz szacunkowe wyliczenia prezentowane przez przedstawicieli Austro-Węgier i Rosji na Międzynarodowym Kongresie zwalczania handlu „żywym towarem” w 1899 r. A. Jakubczak wskazuje na znacząco większe wyobrażenie o rozmiarach tego procederu, które wyłania się z ówczesnych łamów prasowych. Trafnie określa przyczyny tej rozbieżności i stwierdza, że społeczeństwo ziem polskich znalazło się pod wpływem paniki moralnej. Rozdział drugi w całości poświęcony jest teorii paniki moralnej i użyciu jej do wyjaśnienia fenomenu mitu handlu „żywym towarem” zarówno w Europie Zachodniej, jak i na ziemiach polskich. Wydaje się jednak, że w swojej eksplanacji siły mitu o handlu kobietami Autorka, zbyt dużą rolę przypisuje działaczom neoabolicjonistycznym,

12 Rozdział trzeci omawiający strukturę etniczną międzynarodowej prostytucji zawiera tylko jeden podrozdział poruszający zagadnienie mitu kulturowego dotyczącego udziału nie-Żydów w przemycie kobiet. Co ciekawe we Wstępie Autorka stwierdza, że rozdziałów jest sześć. W zamieszczonym tam omówieniu zawartości poszczególnych rozdziałów, tekst który ostatecznie znalazł się w rozdziale szóstym stanowi część rozdziału piątego, a to co Autorka opisuje jako rozdział szósty, w wersji która trafiła do czytelników stało się rozdziałem siódmym. Być może jest to echo długich prac redakcyjnych, a wprowadzona zmiana nie została odnotowana we Wstępie. Nie ma to jednak większego znaczenia dla końcowego odbioru dzieła. 
których możliwości oddziaływania na opinię publiczną nie były wystarczające do wykreowania trwałego mitu.

Kolejnym celem, jaki A. Jakubczak sobie stawia, jest ustalenie rzeczywistego udziału Żydów w handlu kobietami. Na ogólnoeuropejskim tle Autorka przedstawia oskarżenia wobec Żydów o czerpanie zysków z szeroko rozumianej prostytucji, w tym włączenie figury Żyda-handlarza „żywym towarem” do arsenału antysemickich klisz. Potwierdza również (pomijając skalę) udział części ludności żydowskiej w tym procederze, stanowiącym wycinek nielegalnej emigracji z Imperium Rosyjskiego, słusznie zastrzegając, że Żydzi - wbrew obiegowym opiniom - nie zmonopolizowali tej przestępczej dziedziny, ale w niej dominowali. Pewną niekonsekwencję można dostrzec w innym wywodzie A. Jakubczak, w którym za pomocą teorii paniki moralnej wyjaśnia aktywność żydowskiej prasy w opisie zagrożeń związanych z wywożeniem dziewcząt do zamorskich domów publicznych. O ile opisując panikę moralną społeczeństwa polskiego wskazuje jako jej kozła ofiarnego Żydów (istotny składnik tej teorii - grupa kreowana na sprawcę), to w odniesieniu do paniki moralnej społeczności żydowskiej grupy sprawczej nie przedstawia ${ }^{13}$.

A. Jakubczak rewiduje opinię o cichym wspieraniu prostytucji przez władze państw zaborczych. Przekonująco dowodzi, że była to kreacja propagandowa, a władze Rosji, Niemiec i Austro-Węgier nie sprzyjały handlowi „żywym towarem”, co nie wyklucza pojedynczych przypadków pobłażliwości na szczeblu lokalnym.

Autorka sprawnie opisuje proceder handlu kobietami oraz narosłe wokół niego mity. Ujawnia zawarte w kreowanym obrazie fałsze i przekonująco dowodzi ich nieprawdziwości. Stawia również istotne postulaty badawcze, mogące być przydatnymi dla innych historyków. Natomiast pewną wadą prowadzonej przez Autorkę narracji jest nadużywanie kategorycznych stwierdzeń, szczególnie w sferze wyjaśniania przekonań społecznych ${ }^{14}$.

13 Dokładnie rzecz ujmując nie robi tego wprost, z tekstu można domyśleć się, że dla społeczności żydowskiej kozłem ofiarnym byli wywodzący się z tej grupy etnicznej przestępcy. Inna niekonsekwencja, a może tylko niefrasobliwość językowa, znajduje się w rozdziale trzecim. Na stronie 105 Autorka pisze: „Wielokrotnie celowo ignorowano fakt, że żydowscy agenci domów publicznych i inni żydowscy stręczyciele do prostytucji werbowali prawie wylącznie dziewczęta żydowskie, a wśród stręczycieli i nieuczciwych agentów znaleźć można też Polaków chrześcijan". Natomiast na stronie 106 znajdziemy stwierdzenie: „Sprzedaż własnej bratanicy, siostry, córki, żony mogła łatwo zostać uznana przez antysemitów, za oznakę głębokiego zdemoralizowania Żydów, którzy bez skrupułów oddają do domów publicznych bliskie sobie kobiety”.

14 Pozostają jeszcze uwagi drobne. Praca zawiera powtórzenia, zdarza się dwukrotne przedstawianie tych samych informacji, w niemal identycznych zdaniach (wzmianka o Ester Cohn w roz- 
Na koniec warto wskazać „wielkiego nieobecnego” monografii A. Jakubczak. Jak się wydaje jest nim Kościół katolicki, którego wpływu na kształtowanie opinii Polaków w badanym okresie nie sposób przecenić. Autorka nie wspomina ani słowem o udziale księży i prasy katolickiej w kształtowaniu oraz utrwalaniu mitu handlu „żywym towarem", który niewątpliwie istniał, czego dowodzi chociażby część przykładów przytoczonych na początku niniejszego artykułu. Przywoływani wielokrotnie przez A. Jakubczak działacze neoabolicjonistyczni, bądź aktywistki ruchu kobiecego mogli mieć wpływ na wąską grupę zwolenników, natomiast do wprowadzenia do świadomości społecznej mitu handlu kobietami potrzebny był ktoś posiadający realny autorytet, ktoś opiniotwórczy ${ }^{15}$. Kościól, z całą pewnością, ten mit utrwalił. Trwałości mitowi handlu „żywym towarem” nadało również włączenie go do arsenału antysemickich zarzutów i wykorzystywanie w przeciwżydowskiej propagandzie. Niezwykle interesująca byłaby szczegółowa analiza, w jaki sposób do tego doszło.

Drobne w gruncie rzeczy uchybienia, nie mogą przesłonić faktu, że monografia A. Jakubczak ma charakter pionierski i przybliża interesujący epizod w dziejach relacji polsko-żydowskich, wpisując go - co szczególnie istotne - w wymiar historii powszechnej.

\section{Bibliografia}

Bergmann O., Narodowa Demokracja wobec problematyki żydowskiej w latach 1918 -1929, Poznań 1998.

Cała A., Żyd - wróg odwieczny? Antysemityzm w Polsce i jego źródła, Warszawa 2012. Chodźko L., Tableau de la Pologne ancienne et moderne sous le rapport géographique, statistique, géologique etc., 1830.

Jeske-Choiński T., Historia Żydów w Polsce, Warszawa 1919.

Krzywiec G., Polska bez Żydów. Studia z dziejów idei, wyobrażeń i praktyk antysemickich na ziemiach polskich poczatku XX wieku (1905-1914), Warszawa 2017.

dziale pierwszym - s. 49 - jest powtórzona w niemal identycznym zdaniu w rozdziale siódmym - s. 208). Z kolei na stronie 189 użyte zostało określenie „wysokie morale”, w błędnym znaczeniu. 15 Autorka przecenia siłę perswazji neoabolicjonistów oraz znajomość ich działalności wśród współczesnych. „Pierwszy kongres poświęcony walce z handlem kobietami [... ] zmobilizował także społeczeństwo ziem polskich do walki z tzw. handlem »żywym towarem «” (s. 152). Z tak stanowczo sformułowaną opinią nie można się zgodzić. A. Jakubczak jest zresztą w swoich wywodach niekonsekwentna, gdyż zdarza się jej przyznać, że oddźwięk na działalność towarzystw ochrony kobiet wśród proletariatu był „znikomy” (s. 182), co jednak nie przeszkadza jej uznawać kluczowej roli owych towarzystw w kreowaniu mitu handlu „żywym towarem”. 
Moszyński M., Antysemityzm w Królestwie Polskim. Narodziny nowoczesnej ideologii antyżydowskiej (1864-1914), Poznań 2017.

Pałka D., Kościót katolicki wobec Żydów w Polsce międzywojennej, Kraków 2006

Rolicki H., Zmierzch Izraela, Krzeszowice 2004.

Zbyszewski K., Fatszerstwa filmowe, Prosto z mostu, 22 I 1939, nr 4, s. 8.

Nadesłany: 13 VI 2021

Zaakceptowany: 10 IX 2021

Bohdan Głębocki

Uniwersytet im. Adama Mickiewicza w Poznaniu

Wydział Pedagogiczno-Artystyczny

ul. Żelazna $15 / 2$

61-640 Poznań, Poland

e-mail: bohdang@amu.edu.pl 